\title{
An Analysis of Blood Pressure Situations in Japan Using the Large-Scale Medical Checkup Dataset
}

\author{
Kazumitsu Nawata ${ }^{1,2,3}$ (1) \\ ${ }^{1}$ Graduate School of Engineering, University of Tokyo, Tokyo, Japan \\ ${ }^{2}$ Hitotsubashi Institute of Advanced Study, Hitotsubashi University, Tokyo, Japan \\ ${ }^{3}$ Research Institute of Economy, Trade and Industry, Tokyo, Japan \\ Email: nawata@tmi.t.u-tokyo.ac.jp
}

How to cite this paper: Nawata, K. (2021) An Analysis of Blood Pressure Situations in Japan Using the Large-Scale Medical Checkup Dataset. Health, 13, 736-756.

https://doi.org/10.4236/health.2021.137057

Received: June 21, 2021

Accepted: July 12, 2021

Published: July 15, 2021

Copyright $\odot 2021$ by author(s) and Scientific Research Publishing Inc. This work is licensed under the Creative Commons Attribution International License (CC BY 4.0).

http://creativecommons.org/licenses/by/4.0/ Open Access

\begin{abstract}
Background: The high blood pressure (BP) or hypertension is a widely prevalent disease and its costs are very high, and many studies about the relationships between BP and health conditions have been done. We need to know the precise distributions of BP and factors affecting BP. Data and Methods: The distributions of BP are analyzed using 12,877,653 observations obtained from the JMDC Claims Database. The factors that may affect the BP are analyzed by the regression models using 4,615,346 observations. Results: The averages of systolic BP (SBP) and diastolic BP (DBP) are 120.4 and 74.2 $\mathrm{mmHg}$ with standard deviations of 15.9 and $11.3 \mathrm{mmHg}$, respectively. Among the nonmodifiable factors, age and gender are important factors. Among the modifiable factors, variables related to obesity are important risk factors. Taking antihypertensive drugs makes SBP and DBP $13.4 \mathrm{mmHg}$ and $7.8 \mathrm{mmHg}$ lower. Conclusion: The criteria of BP should be carefully determined considering age and gender. The effects of age may be a little different for SBP and DBP. It is necessary to use the proper model to evaluate the effect of antihypertensive drugs correctly. Limitations: The dataset is observatory. Although there are various types of treatment methods and antihypertension drugs, their effects are not evaluated.
\end{abstract}

\section{Keywords}

Blood Pressure, Hypertension, SBP and DBP, Medical Checkups, Antihypertensive Drugs

\section{Introduction}

The high blood pressure (BP) or hypertension is considered as a major risk fac- 
tor of noncommunicable diseases (NCDs). The World Health Organization (WHO) ([1], p. 14) states "Raised blood pressure (hypertension) is considered a major risk factor for the development of several NCDs, including heart and brain diseases." WHO [2] estimated that 1.13 billion people worldwide have hypertension, two-thirds living in low- and middle-income countries, 1 in 4 men and 1 in 5 women had hypertension in 2015, and fewer than 1 in 5 people with hypertension have the problem under control. WHO [3] also provided the percentages of people with hypertension in various countries in 2015 . They declared that "one of the global targets for noncommunicable diseases is to reduce the prevalence of hypertension by $25 \%$ by 2025 (baseline 2010).” Benjamin et al. [4] reported that 874 million adults worldwide had systolic $\mathrm{BP}(\mathrm{SBP}) \geq 140 \mathrm{~mm} \mathrm{Hg}$. According to Blood Pressure UK [5], a general guide of SBP and diastolic BP (DBP) is given by $140 / 90 \mathrm{mmHg}$ (SBP/DBP) or over (that means at least one of them are equal to or higher than the given figures): high blood pressure or hypertension; $120 / 80 \mathrm{mmHg}$ up to $140 / 90 \mathrm{mmHg}$ : pre-high blood pressure; 90/60 mmHg up to $120 / 80 \mathrm{mmHg}$ : ideal blood pressure; and 90/60 $\mathrm{mmHg}$ or lower: low blood pressure.

Although the 140/90 mmHg criterion had been used in the United States, the American College of Cardiology (ACC), American Heart Association (AHA) and nine other organizations presented the new guideline in 2017 (2017 ACC/AHA Guideline). In the 2017 ACC/AHA Guideline, the criterion for hypertension is 130/80 mmHg [6] [7] [8]. Based on the 2017 ACC/AHA Guideline, the Center for Disease Control and Prevention (CDC) [9] classifies the BP category as normal: SBP < $120 \mathrm{mmHg}$ and $\mathrm{DBP}<80 \mathrm{mmHg}$; elevated: SBP is $120-129 \mathrm{mmHg}$ and DBP < $80 \mathrm{mmHg}$; Hypertension Stage 1: SBP is $130-139 \mathrm{mmHg}$ or DBP is 80 - $89 \mathrm{mmHg}$; and Hypertension Stage 2: SBP $\geq 140 \mathrm{mmHg}$ or DBP $\geq 90$ $\mathrm{mmHg}$. Ostchega et al. [10] reported that the prevalence of age-adjusted hypertension in the United States was 45.4\% in the survey period 2017-2018 under the 2027 ACC/AHA Guideline. They also reported that hypertension increased with age.

However, other organizations such as the American Diabetes Association (ADA) [11], the American Academy of Family Physicians (AAFP) [12], an organization that initially adopted the 2017 ACC/AHA Guideline, the European Society of Cardiology and the European Society of Hypertension (ESC/ESH) [13], Hypertension Canada [14] [15], and the Japanese Society of Hypertension [16] maintained the diagnostic guideline of $140 / 90 \mathrm{mmHg}$ for hypertension.

In Japan, the number of hypertension patients who visited hospitals and clinics on the survey day was 9937 thousand in 2017 [17]. The hypertension cost 1.748 trillion yen or $4.0 \%$ of the total medical expenditures, 43.395 trillion yen in fiscal year 2018 [18].

Since hypertension is a widely prevalent disease and its costs are very high, enormous studies about the relationships between BP and health conditions, especially heart diseases (HD), have been done. Framingham Heart Study (FHS) [19] has been continuously conducted 1948 in Framingham, Massachusetts in 
the United States. The study has found that gender (being male), age, cholesterol, SBP and diabetes are risk factors of cardiovascular disease (CVD). Joffres et al. [20] analyzed BP using the Canadian Heart Health Survey and the US National Health and Nutrition Examination Survey (NHANES) III data. They reported about half of diabetes patients had hypertension and were poorly managed. The Prospective Studies Collaboration [21] performed a meta-analysis using individual data for one million adults obtained from the results of 61 prospective studies. They reported that deaths due to ischemic HD increased as SBP and DBP increased in all age cohorts. Rapsomaniki et al. [22] conducted an analysis of 1.25 million people using the CALIBAR (CArdiovascular research using LInked Bespoke studies and Electronic health Records). They concluded that the lifetime risks of CVD with hypertensive individuals were higher than those with normotensive individuals.

The Systolic Blood Pressure Intervention Trial (SPRINT) [23] was a trial in which individuals with SBP of $130 \mathrm{mmHg}$ or higher and an increased CVD risk, but without diabetes, were randomly assigned into two groups. One group was the intensive treatment group with an SBP target less than $120 \mathrm{mmHg}$ and the other was the standard treatment group. Lower rates of fatal and nonfatal major cardiovascular events and of death from any cause in the intensive treatment group were reported in this study. This study was heavily weighted in the 2017ACC/AHA Guideline. The Action to Cardiovascular Risk in Diabetes (ACCORD) study [24] was done to individuals with type 2 diabetes. SPRINT used the style of this study. Unlike SPRINT, the ACCORD study did not find that lowering the SBP below $120 \mathrm{mmHg}$ reduced the major CVD or death rates. Ettehad et al. [25] et al. performed a meta-analysis based on selected 123 studies that focused on lowering BP from 1966 to 2015. They reported that treatments for lowering BP significantly reduced the major CVD risk. Muntner et al. [26] used data from the 2011-2012 and 2013-2014 cycles of NHANES. They mentioned that the 2017 ACC/AHA Guideline would increase the use of hypertension drugs and lower the prevalence of CVD events.

In Japan, the Ministry of Health, Labour and Welfare conducted a survey of SBP and DBP for individuals age 20 or over in 2019 [27]. The averages and standard deviations (SD) of SBP were $132 \mathrm{mmHg}$ and $17.7 \mathrm{mmHg}$ for male, and $126.5 \mathrm{mmHg}$ and $11.4 \mathrm{mmHg}$ for female. Those of DBP were $76.2 \mathrm{mmHg}$ and $11.4 \mathrm{mmHg}$ for male, and $73.1 \mathrm{mmHg}$ and $10.7 \mathrm{mmHg}$ for female. The problem of the survey is that the data contains only 2601 individuals, 1089 males and 1512 females. The Hisayama Study [28] has been done since 1961 to residents of Hisayama in Fukuoka Prefecture. Honda et al. [29] analyzed the data of residents aged $40-84$ for 24 years. They found that age, gender, SBP, hemoglobin A1c (HbAlc), low-density lipoprotein cholesterol (LDL), high-density lipoprotein cholesterol (HDL), smoking and daily exercise as significant factors of CVD. Fujiyoshi et al. [30] analyzed the relation between BP and reported a positive relation between CVD and BP. Asayama et al. [31] analyzed the mortality risk caused by CVD using the dataset of selected 6 cohorts and reported that the 
higher of CVD mortality risk for individuals without treatment even if the effects of various characteristics of individuals were removed.

Nawata et al. [32] evaluated BP using a dataset of 113,979 medical checkup observations obtained from 48,022 individuals belonging to one health insurance society in Japan from April, 2013 to March, 2016. They performed regression analysis and reported that factors affecting BP were age, gender, some eating habits, daily activities, smoking, drinking alcohol, sleeping and wages. Especially, age was a very important factor. Nawata and Kimura [33] discussed about the accuracy of the BP measurements. They found that the "white coat effect" was significant and suggested that the careful payments for upward errors of BP measurements were necessary. Nawata, Sekizawa and Kimura [34] pointed out the problems of the previous BP studies. They are: since the participants and doctors (or researchers) can easily know that the groups (treated or controlled) that they are belonging, the double blinded randomized clinical trials are impossible for the BP studies; trials with positive results are more likely to be published than those with negative or questionable results; researchers themselves might not have strong incentives to publish when the expected results are not obtained; in many studies sponsored by the pharmaceutical companies, biases toward the sponsor's products and conflicts of interest (CI) might occur; and practices are often terminated in the early stages for various reasons especially when expected results are not obtained (termination or endpoint biases). Moreover, in the meta-analyses or systematic reviews, that make the numbers of observations larger by combining various studies, the selection criteria of studies should be determined in advance. However, the criteria were often determined after studies finished. Therefore, we need reliable protocols such as proposed by Yu et al. [35] for the meta-analyses or systematic reviews.

Nawata and Kimura [36] [37] evaluated the medical expenditures using a dataset containing 175,123 medical checkup observations and 6,312,125 receipts from 88,211 individuals obtained from April 2013 to March 2016. They could not find evidence that higher SBP made the medical costs and probability of having HD higher. They concluded the results did not support the new 2017 ACC/AHA guideline for SBP and suggested that a wide and careful range of reviews not only for HD but also for other disease types would be absolutely necessary. Nawata, Sugano and Kimura [38] analyzed the effects of BP, antihypertensive drugs and other factors on the probability of undergoing HD treatments using a dataset containing 83,287 medical check-up and treatment records obtained from 35,504 individuals in 5 fiscal years. They could not find evidence that a higher SBP increased the probability of undergoing HD treatment. However, DBP increased the probability of HD in most of the models. Taking antihypertensive drugs also increased the probability of undergoing HD treatment. Nawata [39] evaluated the risk factors for ischemic stroke using with 59,341 and 50,542 observations. The factors were divided into nonmodifiable and modifiable factors. He reported that age, gender and cerebrovascular disease history were important risk factors among the nonmodifiable factors. For modifiable 
factors, he found that taking antihypertensive drugs and recent large weight change were risk factors but sleeping well significantly reduced the risk of ischemic stroke.

More recently, Kaneko et al. [40] evaluated the heart failure (HF) and atrial fibrillation (AF). They used the JMDC Claims Database from 2005 and 2018 containing 2,196,437 observations. Individuals that were neither taking antihypertensive medication nor had a known history of cardiovascular disease were selected. The Cox-Proportional hazard model was used. 28,056 HF incidents and $7774 \mathrm{AF}$ incidents occurred over a mean follow-up of $1112 \pm 854$ days. They reported that both Stage 1 (SBP $130-139 \mathrm{~mm} \mathrm{Hg}$ or DBP $80-89 \mathrm{~mm} \mathrm{Hg}$ ) and Stage 2 (SBP $\geq 140 \mathrm{~mm} \mathrm{Hg}$ or DBP $\geq 90 \mathrm{~mm} \mathrm{Hg}$ ) hypertension were associated with a greater incidence probability of $\mathrm{HF}$ and AF. They concluded that the ACC/AHA BP classification system might help identify adults at higher risk for $\mathrm{HF}$ and AF incidents. However, the individuals taking antihypertensive drugs were not included and some factors that might affect BP were not considered in their study. Akbay et al. [41] reported that a disruption of the circadian rhythm damaged target organs more seriously than the BP level in masked hypertension.

In addition to traditional NCDs, the relation of the coronavirus disease 2019 (COVID-19), caused by syndrome coronavirus 2 (SARS-CoV-2), and hypertension has become a very important issue that the world has been facing now. WHO ([1], p. viii) states "In the event of a health emergency such as COVID-19, patients with pre-existing NCD conditions such as hypertension and diabetes, become more vulnerable and at higher risk of dying, ...”. The major antihypertensive drugs include angiotensin converting enzyme (ACE) inhibitors and angiotensin II receptor antagonists (ARB) [42]. It was suggested that ACE2 might be related to the infection of SARS [43] [44] and SARS-CoV-2 [45] [46]. ACE inhibitors and $A R B$ might affect the rennin-angiotensin-aldosterone system (RAAS) and the ACE2 generating process. European Medicines Agency (EMA) [47] states "EMA therefore reiterates its previous advice that patients should continue to use ACE inhibitors or ARBs as advised by their doctors." WHO [48] mentions "There is low-certainty evidence that patients on long-term therapy with ACE inhibitors or ARBs are not at higher risk of poor outcomes from COVID-19." ACC, AHA and Heart Failure Society of America (HFSA) [49] admits "but there are no experimental or clinical data demonstrating beneficial or adverse outcomes among COVID-19 patients using ACE-I or ARB medications." Quite a few studies have been doing for these subjects [50]-[69].

Since BP is an important health factor, we need to know the precise distributions of SBP and DBP including healthy individuals. It is also important to find out factors that may affect SBP and DBP. In the study of Nawata [32] et al., the number of observations was limited. Moreover, since the data were obtained from only one health insurance society, the sample selection bias might occur. The sample period was 3 years and it was not possible to evaluate the long term trend of BP. In this paper, I use the JMDC Claims Database and reevaluate BP in Japan. The database contains information of medical payments, treatments and 
$13,157,681$ medical checkup observations obtained from 3,233,271 individuals in Japan. Studies using this size of observations were never done before and it would help us to get fundamental knowledge of the BP situation. First, the distributions of SBP and DBP are evaluated, and then factors affecting the SBP and DBP are analyzed.

\section{Data and Distribution of BP}

\subsection{Medical Checkup Observations}

In Japan, the Industrial Safety and Health Act requires for most employees age 40 or older to take mandatory medical checkups once a year independent of their health conditions. Their family members may also take medical checkups on a voluntary basis. In this paper, I use the JMDC Claims Database that is a nationwide health claims database collecting medical information from various health insurance societies throughout Japan. The results of health and medical checkups, including BP measurements, of all employees (including normal healthy ones) and their family members (voluntary) of companies joining the health insurance societies are available. It contains 13,157,681 medical checkup observations obtained from 3,233,271 individuals, and the sample period is the January 2005 and to September 2019; that is, for 15 years and 9 months.

\subsection{Distributions of SBP and DBP}

Figure 1 and Figure 2 are the distributions of SBP and DBP obtained from $12,877,653$ medical checkup observations and the summary of SBP and DBP distribution is given in Table 1 . The averages and SD of all observations are $120.4 \mathrm{mmHg}$ and $15.9 \mathrm{mmHg}$ for SBP and $74.2 \mathrm{mmHg}$ and $11.3 \mathrm{mmHg}$ for DBP, respectively. Among all observations, $10.6 \%$ and $25.4 \%$ are classified as SP hypertension for $140 \mathrm{mmHg}$ and $130 \mathrm{mmHg}$ criteria, respectively. On the other hand, $9.6 \%$ and $32.3 \%$ are classified as DP hypertension for $90 \mathrm{mmHg}$ and 80 mmHg criteria. For $140 / 90$ and $130 / 90 \mathrm{mmHg}$ criteria, $14.0 \%$ and $38.0 \%$ are classified as hypertension.

\section{No. of observations}

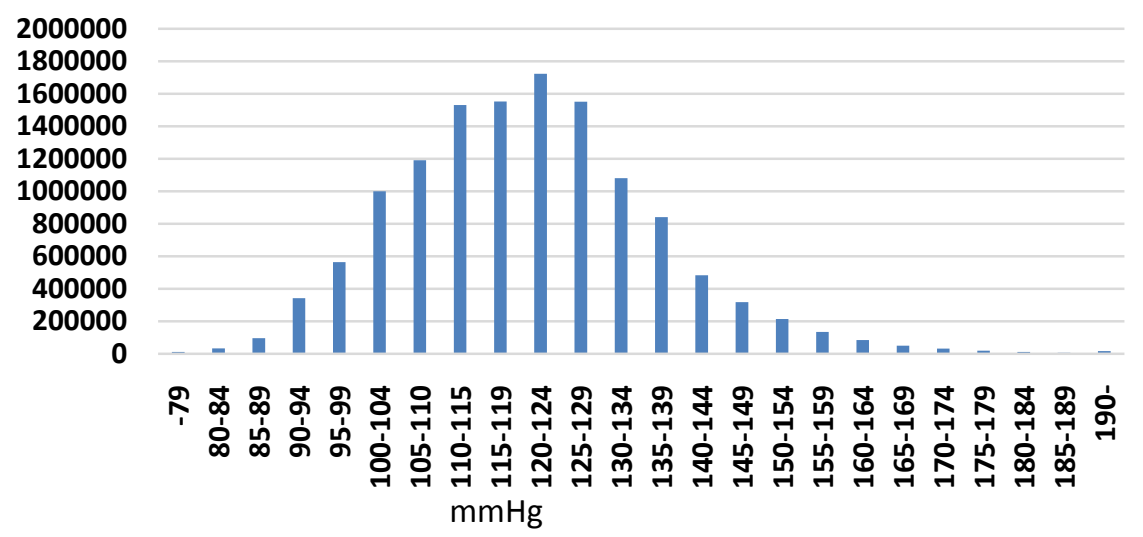

Figure 1. Distribution of systolic blood pressure (SBP). 
No. of observations

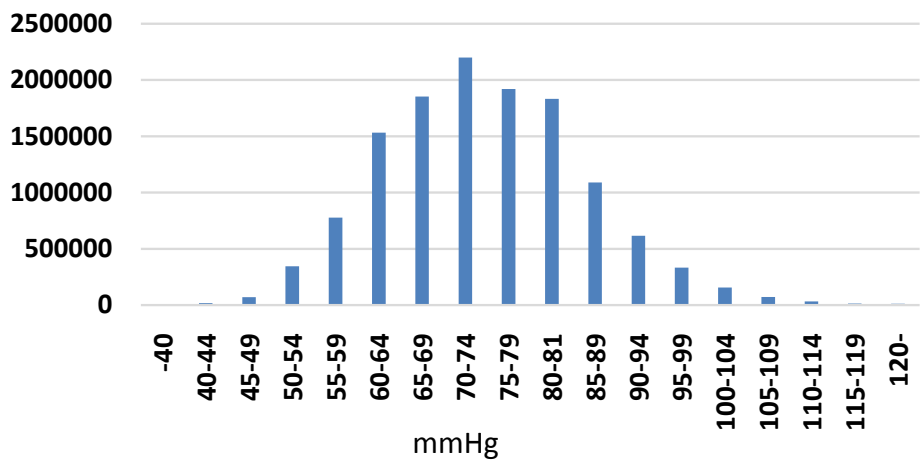

Figure 2. Distribution of systolic blood pressure (DBP).

Table 1. Summary of BP distributions.

\begin{tabular}{ccccccc}
\hline & \multicolumn{2}{c}{ All } & \multicolumn{2}{c}{ Male } & \multicolumn{2}{c}{ Female } \\
\hline & SBP & DBP & SBP & DBP & SBP & DBP \\
\hline Average & 120.4 & 74.2 & 123.1 & 76.3 & 115.0 & 70.0 \\
Median & 120 & 74 & 122 & 76 & 113 & 69 \\
Maximum & 297 & 150 & 297 & 150 & 270 & 150 \\
Minimum & 60 & 30 & 62 & 30 & 60 & 30 \\
SD & 15.9 & 11.7 & 14.9 & 11.3 & 16.5 & 11.3 \\
No. of observations & \multicolumn{2}{c}{$12,877,653$} & \multicolumn{2}{c}{$8,704,744$} & \multicolumn{2}{c}{$4,172,909$} \\
\hline
\end{tabular}

SD: Standard deviation

\section{Analyses of Factors Affecting BP by Regression Models}

In this section, I analyze the factors that may affect the BP. Age, gender, a type of a membership and time trend are used as nonmodifiable factors. Body mass index (BMI), results of blood and urine tests, eating habits, physical conditions, alcohol consumptions and smoking are used as nonmodifiable factors.

\subsection{SBP}

First, I consider a simple model to evaluate the gross effects of nonmodifiable factors given by (Model 1A):

$$
S B P_{i}=\beta_{1}+\beta_{2} \text { Age } 1+\beta_{3} \text { Age1 }^{2}+\beta_{4} \text { Family }+\beta_{5} \text { Female }+\beta_{6} t 1+u_{i}
$$

where Agel $=$ age-17 because the youngest age in the data set is 18 and $t 1$ represents the time trend, $t 1=$ year-2004. Excluding observations with missing values, a total of $12,877,653$ observations are used in the estimation. The annual numbers of observations are given in Figure 3. The average and SD of age are 45.4 and 11.3 years, respectively. The effect of age may not be a linear function, so the quadric term of Agel is included. Female represents gender (1: female, 32.4\%; 0: otherwise, 67.6\%), and Family represents a type of memberships (1: family member, $15.6 \%$; 0 : employee, $84.4 \%)$. The results of the estimation are given under "Model 1A" in Table 2. Since the number of observations is quite 
No. of observations

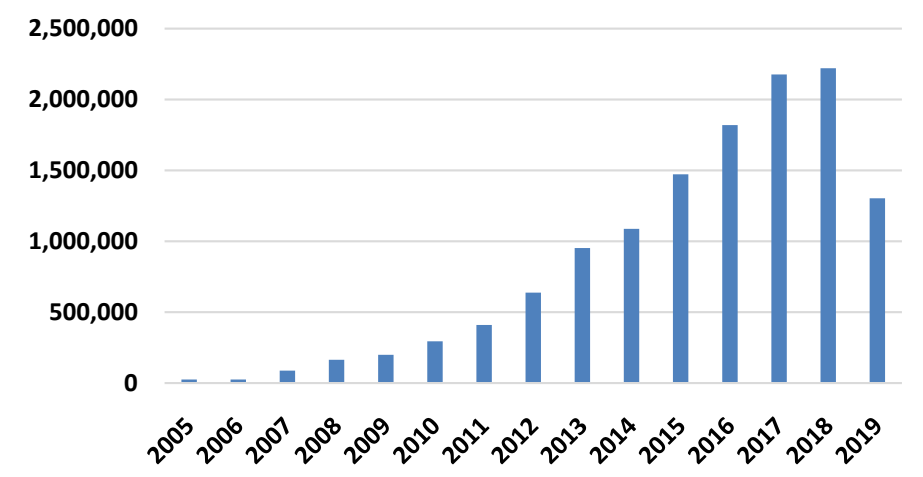

Figure 3. Annual numbers of observations.

Table 2. Results of estimation: SBP equations.

\begin{tabular}{|c|c|c|c|c|c|c|}
\hline \multirow[b]{2}{*}{ Variable } & \multicolumn{2}{|c|}{ Model 1A } & \multicolumn{2}{|c|}{ Model 1B } & \multicolumn{2}{|c|}{ Model 1C } \\
\hline & Estimates & SE & Estimates & SE & Estimates & $\mathrm{SE}$ \\
\hline Constant & 106.1904 & 0.0445 & 76.4662 & 0.1007 & 70.4536 & 0.1206 \\
\hline Agel & 0.0103 & 0.0015 & -0.1176 & 0.0032 & -0.2974 & 0.0050 \\
\hline Agel $^{2}$ & 0.0064 & 0.0000 & 0.0076 & 0.0001 & 0.0063 & 0.0001 \\
\hline Female & -7.8498 & 0.0113 & -4.1308 & 0.0207 & -4.2669 & 0.0209 \\
\hline Family & -0.6589 & 0.0148 & 0.3901 & 0.0221 & 0.3117 & 0.0225 \\
\hline$t 1$ & -0.2322 & 0.0015 & -0.2395 & 0.0033 & -0.2607 & 0.0033 \\
\hline$B M I$ & & & 1.3260 & 0.0025 & 1.5357 & 0.0032 \\
\hline$H D L$ & & & 0.0739 & 0.0005 & 0.0703 & 0.0005 \\
\hline$L D L$ & & & 0.0133 & 0.0002 & -0.0032 & 0.0003 \\
\hline Triglyceride & & & 0.0129 & 0.0001 & 0.0133 & 0.0001 \\
\hline$A L T$ & & & -0.0126 & 0.0007 & -0.0133 & 0.0008 \\
\hline$A S T$ & & & 0.0428 & 0.0011 & 0.0483 & 0.0015 \\
\hline$G G P$ & & & 0.0174 & 0.0002 & 0.0220 & 0.0002 \\
\hline B_Sugar & & & 0.1199 & 0.0006 & 0.1337 & 0.0007 \\
\hline$H b A 1 c$ & & & -2.0173 & 0.0175 & -1.8342 & 0.0197 \\
\hline U_Sugar & & & -0.5545 & 0.0186 & -0.4784 & 0.0209 \\
\hline U_Protein & & & 0.7996 & 0.0142 & 1.3231 & 0.0168 \\
\hline Weight_1 & & & -0.6715 & 0.0158 & -0.7016 & 0.0155 \\
\hline Weight_20 & & & 0.2249 & 0.0174 & 0.4025 & 0.0177 \\
\hline Eat_fast & & & -0.2824 & 0.0147 & -0.1661 & 0.0146 \\
\hline Late_supper & & & -0.1235 & 0.0153 & -0.2055 & 0.0151 \\
\hline No_breakfast & & & 0.7229 & 0.0183 & 0.5541 & 0.0182 \\
\hline Exercise & & & -0.2817 & 0.0172 & -0.3971 & 0.0174 \\
\hline Activity & & & 0.0632 & 0.0147 & 0.0273 & 0.0147 \\
\hline Speed & & & -0.0963 & 0.0138 & -0.2862 & 0.0139 \\
\hline Sleep & & & 0.3104 & 0.0138 & 0.3071 & 0.0137 \\
\hline
\end{tabular}




\begin{tabular}{|c|c|c|c|c|c|}
\hline \multicolumn{6}{|l|}{ Continued } \\
\hline Alcohol_freq & & 0.9488 & 0.0131 & 1.0050 & 0.0131 \\
\hline Alcohol_amount & & -0.0366 & 0.0089 & 0.0557 & 0.0088 \\
\hline Smoke & & -0.6200 & 0.0166 & -0.9886 & 0.0169 \\
\hline E(Antihypertensive) & & & & -13.3434 & 0.1264 \\
\hline $\mathrm{R}^{2}$ & 0.1254 & \multicolumn{2}{|c|}{0.2432} & \multicolumn{2}{|c|}{0.2451} \\
\hline No. of Observations & $12,877,653$ & \multicolumn{2}{|c|}{$4,620,677$} & \multicolumn{2}{|c|}{$4,615,346$} \\
\hline
\end{tabular}

SE: Standard error.

larger, all variables are highly significant. SBP increases by $3.4 \mathrm{mmHg}$ from age 40 to 50 and $5.0 \mathrm{mmHg}$ from age 50 to 60 , respectively. The estimate of Female is $-7.8 \mathrm{mmHg}$ and there is a big difference between males and females. Being a family member slightly reduces SBP. The estimate of $t 1$ is negative and we admit ted that there is a declining time trend in BP.

Next, I consider the model containing both nonmodifiable and modifiable factors. First, I consider the model (Model 1B):

$$
\begin{aligned}
S_{B P}= & \beta_{1}+\beta_{2} \text { Age } 1+\beta_{3} \text { Age }{ }^{2}+\beta_{4} \text { Female }+\beta_{5} t 1+\beta_{6} B M I+\beta_{7} H D L \\
& +\beta_{8} L D L+\beta_{9} \text { Triglyceride }+\beta_{10} A L T+\beta_{11} A S T+\beta_{12} G G P+\beta_{13} B \_ \text {Sugar } \\
& +\beta_{14} \text { HbA1c }+\beta_{15} U \_ \text {Sugar }+\beta_{16} U \_ \text {Protein }+\beta_{17} \text { Weight_ } 1 \\
& +\beta_{18} \text { Weight_20 }+\beta_{19} \text { Eat_fast }+\beta_{20} \text { Late_supper }+\beta_{21} \text { No_breakfast } \\
& +\beta_{22} \text { Exercise }+\beta_{23} \text { Activity }+\beta_{24} \text { Walk_fast }+\beta_{25} \text { Sleep } \\
& +\beta_{26} \text { Alcohol_freq }+\beta_{27} \text { Alcohol_amount }+\beta_{28} \text { Smoke }+u_{i} .
\end{aligned}
$$

The definition and summary of these variables are given in Table 3. A total of 4,620,677 observations that have no missing values for any of the explanatory variables are used. The results of the estimation are given under "Model 1B" in Table 2. As before, all the variables are significant at any reasonable level; even the largest p-value is less than $10^{-6}$. For age, the estimate of Agel is negative and that of $\mathrm{Agel}^{2}$ is positive. Since both of $\mathrm{Agel}$ and $\mathrm{Agel}^{2}$ are functions of age, they must evaluate simultaneously (the estimate of Agel determines the age which minimizes SBP). From these estimates, we can calculate that the SBP takes the minimum value at age around 25, and it increases by $3.0 \mathrm{mmHg}$ from age 40 to 50 and $4.6 \mathrm{mmHg}$ from age 50 to 60 , respectively. For gender and the time trend, we get the similar results as those of Model $1 \mathrm{~A}$ and these variables are quite important even after various characteristics of individuals are considered. For the variables measured at the medical checkups, the estimates of $B M I, H D L L D L$, Triglyceride, AST, GGP, B_Sugar and $U \_$Protein are positive, and those of ALT, $H b A 1 c$ and $U_{-}$Sugar are negative. For the weight changes, the estimate of Weight_1 is positive but that of Weight_20 is negative. For eating habits and physical conditions, the estimates of No_breakfast, Activity and Sleep are positive but those of Eat_fast, Late_supper, Exercise and Speed are negative. For alcohol drinking, the estimate of Alcohol_freq is positive but that of Alcohol_amount becomes negative. The estimate of Smoke becomes negative. 
Table 3. Definitions and summaries of explanatory variables.

\begin{tabular}{|c|c|c|c|}
\hline \multirow{2}{*}{ Variable } & \multirow{2}{*}{ Definition } & \multicolumn{2}{|c|}{ Summary } \\
\hline & & Average & $\mathrm{SD}$ \\
\hline age & & 47.9 & 9.73 \\
\hline Female & 1: Female; 0: otherwise & \multicolumn{2}{|c|}{$1: 39.5 \% ; 0: 60.5 \%$} \\
\hline Family & 1: Famlly member; 0: otherwise & \multicolumn{2}{|c|}{ 1: $22.2 \% ; 0: 77.8 \%$} \\
\hline$B M I$ & body mass index $=$ height $(\mathrm{m}) /$ weight $(\mathrm{kg})^{2}$ & 23.0 & 3.67 \\
\hline$H D L$ & high density lipoprotein cholesterol blood, mg/dL & 63.6 & 16.85 \\
\hline$L D L$ & low-density lipoprotein cholesterol, mg/dL & 121.7 & 30.98 \\
\hline Triglyceride & $\mathrm{mg} / \mathrm{dL}$ & 108.1 & 85.84 \\
\hline$A L T$ & alanine aminotransferase, $\mathrm{U} / \mathrm{L}$ & 22.3 & 10.68 \\
\hline$A S T$ & aspartate aminotransferase, $\mathrm{U} / \mathrm{L}$ & 23.2 & 17.68 \\
\hline$G G P$ & $\gamma$-glutamyl transferase, units per lite & 95.6 & 18.49 \\
\hline B_Sugar & blood sugar, mg/dL & 38.1 & 45.46 \\
\hline$H b A 1 c$ & hemoglobin Alc, \% & 5.5 & 0.61 \\
\hline U_Sugar & $\begin{array}{l}\text { urine sugar, integers of } 1-5 ; 1: \text { undetected, } 2: \text { around } 50 \\
\mathrm{mg} / \mathrm{dL}, 3: \text { around } 100 \mathrm{mg} / \mathrm{dL}, 4: \text { around } 250 \mathrm{mg} / \mathrm{dL} \text { and } 5: \\
\text { around } 500 \mathrm{mg} / \mathrm{dL} \text { or over; } 1 \text { is normal, } 5 \text { is worst }\end{array}$ & $\begin{array}{r}1: 97.82 \% \\
0.53 \% ; \\
5: 0 .\end{array}$ & $\begin{array}{l}0.47 \% ; 3: \\
0.39 \% \\
9 \%\end{array}$ \\
\hline U_Protein & $\begin{array}{l}\text { urine protein, integers of } 1-5 ; 1 \text { : undetected, } 2 \text { : around } 151 \\
\mathrm{mg} / \mathrm{dL}, 3: \text { around } 30 \mathrm{mg} / \mathrm{dL}, 4: \text { around } 100 \mathrm{mg} / \mathrm{dL} \text { and } 5 \text { : } \\
\text { around } 250 \mathrm{mg} / \mathrm{dL} \text { or over; } 1 \text { is normal, } 5 \text { is worst }\end{array}$ & $\begin{array}{r}1: 88.96 \% \\
2.38 \% ; \\
5: 0 .\end{array}$ & $\begin{array}{l}7.91 \% ; 3: \\
0.59 \% \\
5 \%\end{array}$ \\
\hline Weight_1 & 1 : weight changed by $3 \mathrm{~kg}$ or more in a year; 0 : otherwise & 1: $26.5 \%$; & : $73.5 \%$ \\
\hline Weight_20 & weight increased by $10 \mathrm{~kg}$ or more from age 20 & 1: $35.3 \%$; & : $64.7 \%$ \\
\hline Eat_fast & 1: eating faster than other people; 0 : otherwise & $1: 32.5 \%$ & $67.5 \%$ \\
\hline Late_supper & $\begin{array}{l}\text { 1: eating supper within two hours before bedtime three } \\
\text { times or more in a week; } 0 \text { : otherwise, }\end{array}$ & 1: $32.1 \%$; & : $67.9 \%$ \\
\hline No_breakfast & $\begin{array}{l}\text { 1: not eating breakfast three times or more in a week; } 0 \text { : } \\
\text { otherwise }\end{array}$ & 1: $18.1 \%$; & $81.9 \%$ \\
\hline Exercise & $\begin{array}{l}\text { 1: doing exercise for } 30 \text { minutes or more twice or more in a } \\
\text { week for more than a year; } 0 \text { otherwise }\end{array}$ & $1: 21.7 \%$ & : $78.3 \%$ \\
\hline Activity & $\begin{array}{l}\text { 1: doing physical activities (walking or equivalent) for one } \\
\text { hour or more daily, } 0 \text { : otherwise }\end{array}$ & 1: $35.7 \%$; & $64.3 \%$ \\
\hline Speed & $\begin{array}{l}\text { 1: walking faster than other people of a similar age and the } \\
\text { same gender; } 0 \text { : otherwise }\end{array}$ & 0: $45.1 \%$; & : $54.9 \%$ \\
\hline Sleep & 1: sleeping well; 0 : otherwise & 1: $45.1 \%$; & : $54.9 \%$ \\
\hline Alcohol_freq & $0:$ not drinking alcoholic drinks, 1 : sometimes, 2 : everyday & $\begin{array}{r}0: 40.9 \% \text {; } \\
2: 25\end{array}$ & $4 \%$ \\
\hline Alcohol_amount & $\begin{array}{l}\text { 0: not drinking; } 1 \text { : drinking less than } 180 \mathrm{ml} \text { of Japanese sake } \\
\text { wine (with an alcohol percentage of about } 15 \% \text { ) or } \\
\text { equivalent alcohol in a day when drinking; } 2 \text { : drinking } 180 \text { - } \\
360 \mathrm{ml} \text {; } 3 \text { : drinking } 360 \text { - } 540 \mathrm{ml} \text {; } 4 \text { : drinking } 540 \mathrm{ml} \text { or more, }\end{array}$ & $\begin{array}{r}0: 40.9 \% \text {; } \\
2: 22.6 \% \text {; } \\
4: 3\end{array}$ & $\begin{array}{l}1: 22.2 \% \\
: 10.6 \% \\
7 \%\end{array}$ \\
\hline Smoke & 1: smoking; 0: otherwise & 1: $25.1 \%$; & 2: $74.9 \%$ \\
\hline Antihypertensive & 1: taking antihypertensive drugs, 0 : otherwise & 1: $11.7 \%$; & 0: 88.3\% \\
\hline
\end{tabular}

SD: Standard deviation; $G G P, A S T$ and $A L T$ are mainly related to liver functions. 
For BP, taking the antihypertensive drugs or not is an important factor. However, whether an individual takes antihypertensive drugs depends on the BP level. In other words, an individual with higher BP is more likely to take antihypertensive drugs. So, we cannot directly use Antihypertensive (taking antihypertensive drugs: 1; 0: otherwise) dummy because of the endogeneity problem (actually, if we directly use Antihypertensive in the regression equation, its estimate becomes $+4.80 \mathrm{mmHg}$ ). Nawata, Sekizawa and Kimura [34] suggested a method to take the expected value of the variable to solve the endogeneity problem, the following model evaluating the effect of Antihypertensive. (Model 1C):

$$
S B P_{i}=x_{i}^{\prime} \beta+\gamma E(\text { Antihypertensive })+v_{i},
$$

where $x_{i}$ and $\beta$ are vectors of the explanatory variables and parameters in Model 1B, respectively. The model evaluates the net effects of variables including Antihypertensive. Note that the error terms become heteroscedastic, White's method [70] is used to calculate the standard error. A total of 4,615,346 observations that have no missing values for any of the explanatory variables are used. Although the number of observations is $0.12 \%$ fewer than the previous model, the values of explanatory variables are very similar. In terms of averages, the largest relative error is $0.036 \%$. So, I do not present the summaries of variables for this model to avoid unnecessary duplications. $E$ (Antihypertensive) is estimated by the probit model and the results of the probit estimation are given in Table 4. The results of estimation are given under "Model 1C" in Table 2. The results show the very similar tendency to those of Model 1B for the estimates of

Table 4. Results of estimation: Probit model.

\begin{tabular}{cccccc}
\hline Variable & Estimates & SE & Variable & Estimates & SE \\
\hline Constant & -6.2393 & 0.0165 & U_Sugar & -0.0058 & 0.0019 \\
Agel & 0.1358 & 0.0008 & U_Protein & 0.1728 & 0.0016 \\
Age1 ${ }^{2}$ & -0.0009 & 0.0000 & Weight_1 & -0.1456 & 0.0022 \\
Female & -0.1174 & 0.0031 & Weight_20 & 0.0438 & 0.0017 \\
Family & 0.0045 & 0.0034 & Eat_fast & 0.0446 & 0.0011 \\
t1 & -0.0104 & 0.0005 & Late_supper & 0.0582 & 0.0019 \\
BMI & 0.0918 & 0.0003 & No_breakfast & -0.0215 & 0.0021 \\
HDL & -0.0019 & 0.0001 & Exercise & -0.0867 & 0.0027 \\
LDL & -0.0064 & 0.0000 & Activity & -0.0231 & 0.0022 \\
Triglyceride & 0.0001 & 0.0000 & Speed & -0.0158 & 0.0020 \\
ALT & 0.0041 & 0.0001 & Sleep & -0.0722 & 0.0019 \\
AST & 0.0025 & 0.0001 & Alcohol_freq & 0.0111 & 0.0021 \\
GGP & -0.0014 & 0.0001 & Alcohol_amount & 0.0566 & 0.0022 \\
B_Sugar & 0.0013 & 0.0000 & Smoke & -0.008199 & 0.001869 \\
HbA1c & 0.0194 & 0.0020 & & & \\
Log likelihood & -1243885 & & & \\
\hline
\end{tabular}

SE: Standard error 
$X_{i}$. Except $L D L$ and Alcohol_amount, the estimates have the same signs. For the estimate of E(Antihypertensive), representing the reduction of SBP by taking antihypertensive drugs, is $-13.3 \mathrm{mmHg}$ and significant reduction of SBP is admitted by taking antihypertensive drugs.

\subsection{DBP}

DBP is analyzed using the same three models as before. The models are:

Model 2A:

$$
D B P_{i}=\beta_{1}+\beta_{2} \text { Age } 1+\beta_{3} \text { Age1 }^{2}+\beta_{4} \text { Family }+\beta_{5} \text { Female }+\beta_{6} t 1+u_{i} .
$$

Model 2B:

$$
\begin{aligned}
D B P_{i}= & \beta_{1}+\beta_{2} \text { Age } 1+\beta_{3} \text { Age }^{2}+\beta_{4} \text { Female } \beta_{5} t 1+\beta_{6} B M I+\beta_{7} H D L \\
& +\beta_{8} L D L+\beta_{9} \text { Triglyceride }+\beta_{10} A L T+\beta_{11} A S T+\beta_{12} G G P+\beta_{13} B \_ \text {Sugar } \\
& +\beta_{14} \text { HbA1c }+\beta_{15} U_{-} \text {Sugar }+\beta_{16} U \_ \text {Protein }+\beta_{17} \text { Weight_1 } \\
& +\beta_{18} \text { Weight_20+ } \beta_{19} \text { Eat_fast }+\beta_{20} \text { Late_supper }+\beta_{21} \text { No_breakfast } \\
& +\beta_{22} \text { Exercise }+\beta_{23} \text { Activity }+\beta_{24} \text { Walk_fast }+\beta_{25} \text { Sleep } \\
& +\beta_{26} \text { Alcohol_freq }+\beta_{27} \text { Alcohol_amount }+\beta_{28} \text { Smoke }+u_{i} .
\end{aligned}
$$

Model 2C:

$$
D B P_{i}=x_{i}^{\prime} \beta+\gamma E(\text { Antihypertensive })+v_{i} .
$$

The numbers of the observations are the same as the SBP case. The results of the estimation are given in Table 5. As the SBP case, almost variables are significant at any reasonable. The p-values are quite small except Eat_fast in Model B (the p-value is 0.0011 ) and Speed in Moles 2B and 2C (p-values are 0.0001 and 0.0013 , respectively). The estimates of Agel $^{2}$ become negative in Models $2 \mathrm{~A}$ and 2C. In Model 2A, in which the gross effect of age is evaluated, DBP increases by $3.2 \mathrm{mmHg}$ from age 40 to 50 and $1.9 \mathrm{mmHg}$ from age 50 to 60 , respectively. The

\begin{tabular}{|c|c|c|c|c|c|c|}
\hline \multirow[b]{2}{*}{ Variable } & \multicolumn{2}{|c|}{ Model 2A } & \multicolumn{2}{|c|}{ Model 2B } & \multicolumn{2}{|c|}{ Model 2C } \\
\hline & Estimates & SE & Estimates & SE & Estimates & SE \\
\hline Constant & 77.3782 & 0.0321 & 49.9643 & 0.0878 & 42.7498 & 0.1210 \\
\hline Agel & 0.6639 & 0.0011 & -0.1176 & 0.0032 & 0.4283 & 0.0023 \\
\hline $\mathrm{Agel}^{2}$ & -0.0062 & 0.0000 & 0.0076 & 0.0001 & -0.0021 & 0.0000 \\
\hline Female & -5.7849 & 0.0082 & -3.5992 & 0.0150 & -3.6802 & 0.0150 \\
\hline Family & -1.5058 & 0.0106 & -0.5272 & 0.0159 & -0.5713 & 0.0160 \\
\hline
\end{tabular}
effects of most other variables affecting DBP are similar to those in the SBP models. The signs of estimates are the same as those of the SBP models except ALT in Models 2B and 2C, and Activity and Alcohol_amount in Model 2B. For the estimate of $E$ (Antihypertensive), representing the reduction of DBP by taking antihypertensive drugs, is $-7.8 \mathrm{mmHg}$ and significant reduction of DBP is also admitted by taking antihypertensive drugs.

Table 5. Results of estimation: DBP equations. 


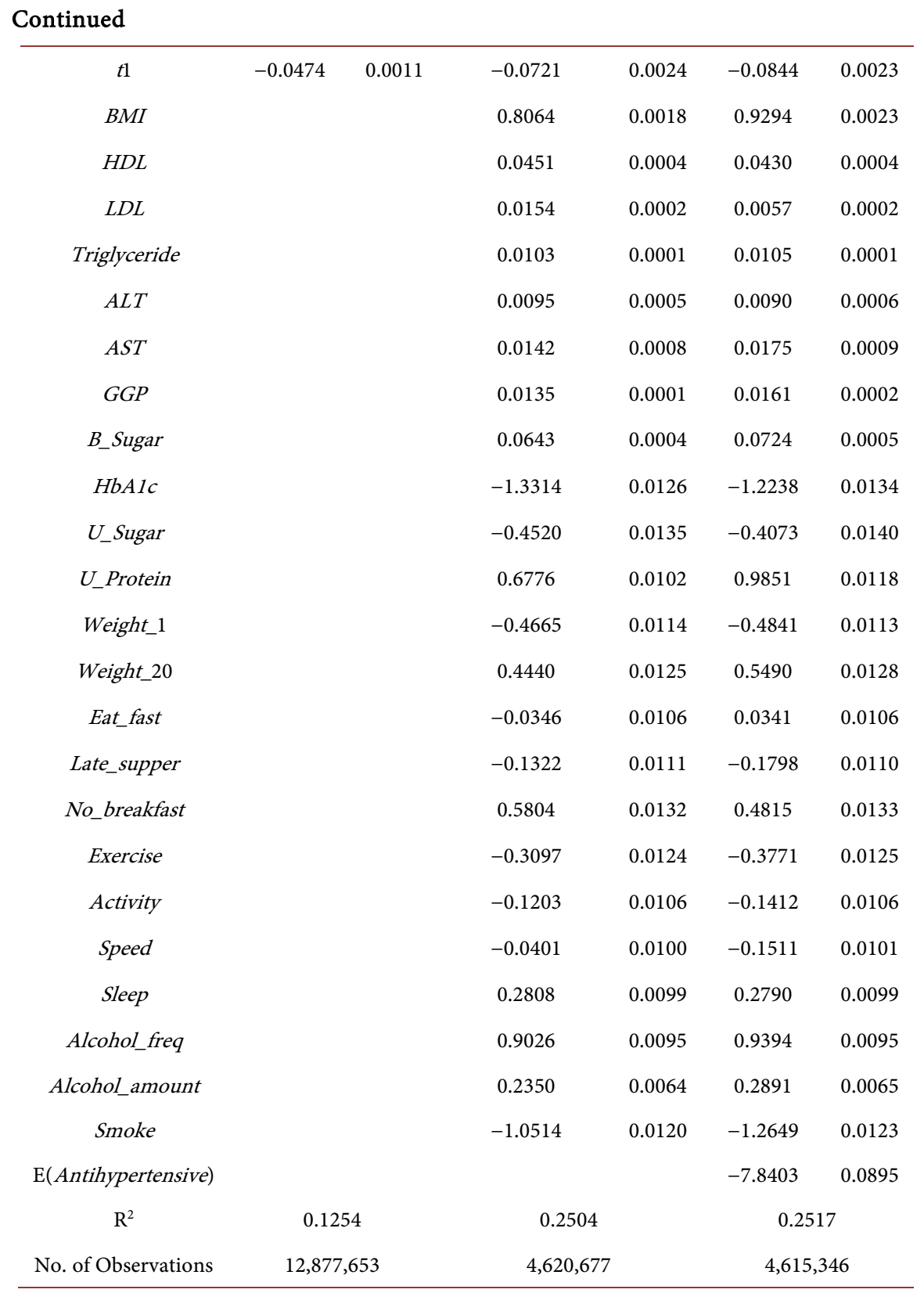

SE: Standard error.

\section{Discussion}

Age is a very important variable affecting both $\mathrm{SBP}$ and $\mathrm{DBP}$ as previous studies. The quadric terms of age are significant, and the effects of age may not be a linear function. Moreover, the effects of age are a little different between different SBP and DBP. The estimates of quadric terms of age are positive for SBP. SBP increases rapidly as age increases. However, for DBP, the estimates of quadric terms are negative in Models 2A and 2C. In these models, DBP becomes higher as an individual becomes older; however, the increasing rate becomes smaller. Miura Nagai and Ohkubo [71] reported that SBP had been declining for 50 years for all ages and genders; however, for DBP, the same trend was observed for fe- 
males but not males. Therefore, the effects of age should be carefully revised to get more precise evaluations for both SBP and DBP.

A large difference between males and females is admitted both in SBP and DBP in all models. As pointed out before [32], this fact raises the question of whether the same BP criterion should be used for hypertension regardless of gender. Being a family member makes SBP higher in Models $1 \mathrm{~B}$ and $1 \mathrm{C}$, and DBP lower in Models 2A, 2B and 2C. But the effects are rather small $(0.3 \mathrm{mmHg}$ and $-0.6 \mathrm{mmHg}$ in Models $1 \mathrm{C}$ and $2 \mathrm{C}$, respectively). The declining time trends of both SBP and DBP are observed in all models; that is consistent to the previous study [72].

For the evaluation of modifiable variables, not only values of estimates but also dispersions of variables become important. The results of Models 1C and 2C are used in the following analysis. For quantitative variables, the effect of a variable is measured by a product of its estimate and SD. The values of $B M I$ and B_sugar become $4.8 \mathrm{mmHg}$ and $5.5 \mathrm{mmHg}$ for SBP and $3.0 \mathrm{mmHg}$ and 2.9 mmHg for DBP. This means that BMI and $B \_$sugar are very important to control $\mathrm{BP}$, and these variables are related to obesity and preventing obesity may improve the $\mathrm{BP}$ conditions. The absolute values of other variables are at most 1.2 $\mathrm{mmHg}$ for SBP and $0.9 \mathrm{mmHg}$ for DBP. The effects of qualitative variables are measured by their estimates except U_Protein, Alcohol_freq and Alcohol_amount. (Although $U_{-}$Sugar takes from 1 to 5, the most of observations take 1 or 2.) The effect of Smoke is $-1.0 \mathrm{mmHg}$ and $-1.3 \mathrm{mmHg}$ for SBP and DBP, however, other negative effects of smoking are not considered in this study. The effects of other variables are relatively small and the absolute effects are less than $0.6 \mathrm{mmHg}$ for both SBP and DBP. SBP and DBP increase by 1.3 $\mathrm{mmHg}$ and $1.0 \mathrm{mmHg}$ if $U_{-}$Protein increases by 1 . Since the percentages of observations for $U_{-}$Protein of 2, 3, 4 and 5 are $7.9 \%, 2.4 \%, 0.4 \%$ and $0.8 \%$, respectively, $U_{-}$Protein is also an important variable to control BP. In case of alcohol drinking, the SBP and DBP of heavy drinkers (who drink $540 \mathrm{ml}$ or more every day) are $2.2 \mathrm{mmHg}$ and $3.0 \mathrm{mmHg}$ higher than those of non-alcohol drinkers.

The taking antihypertensive drugs make SBP and DBP $13.4 \mathrm{mmHg}$ and 7.8 $\mathrm{mmHg}$ lower, and significant reduction is admitted. Note that if we directly use the Antihypertensive dummy in the regression equations, the estimates become $+4.8 \mathrm{mmHg}$ and $+3.3 \mathrm{mmHg}$; that shows the importance and usefulness of the method used in this study.

\section{Conclusions}

In this paper, BP in Japan is evaluated using the JMDC Claims Database containing 13,157,681 medical checkup observations obtained from 3,233,271 individuals from January, 2005 to September, 2019. I first evaluate the BP distributions of $12,877,653$ observations in which the BP data are available. The averages and SD of all observations are $120.4 \mathrm{mmHg}$ and $15.9 \mathrm{mmHg}$ for SBP and 74.2 $\mathrm{mmHg}$ and $11.3 \mathrm{mmHg}$ for DBP, respectively. For $140 / 90$ and $130 / 90 \mathrm{mmHg}$ 
criteria, $14.0 \%$ and $38.0 \%$ are classified as hypertension.

Then, the factors that may affect BP are evaluated using regression models. Age is a very important variable affecting both SBP and DBP. The quadric terms of age are significant, and the effects of age may not be a linear function. The effects of age are a little bit different between SBP and DBP. The estimates of quadric term of age are positive for SBP but negative for DBP in all models except Model 2B. SBP increases rapidly as age increases. DBP becomes higher as an individual becomes older; however, the increasing rate becomes smaller in Models $2 \mathrm{~A}$ and $2 \mathrm{C}$. BP of females is significantly lower than that of males in all models; that fact raises a question that the gender should be considered in the hypertension criteria. Declining trends are admitted in both SBP and DBP.

Among modifiable factors, BMI and blood sugar level are very important factors. These are related to obesity and preventing obesity might improve the $\mathrm{BP}$ conditions. BP of heavy alcohol drinkers is significantly higher than nonalcohol drinkers. Taking antihypertensive drugs makes SBP and DBP $13.4 \mathrm{mmHg}$ and $7.8 \mathrm{mmHg}$ lower, and significant reduction is admitted. If we directly use the Antihypertensive dummy in the regression equations, the estimates become positive and the importance and usefulness of the method used in this study are clearly showed.

In this study, the distributions and factors affecting BP are analyzed. The criteria of BP should be carefully determined considering age and gender of individuals. The effects of BP on other diseases are not evaluated. Although there are various types of treatment methods and antihypertension drugs, their effects are not evaluated, either. These are subjects to be studied in the future.

\section{Acknowledgements}

This study is a part of the research project "Basic research for exploring the ideal medical intervention after the advent of the new coronavirus" by Research Institute of Economy, Trade and Industry (RIETI). The JMDC Claims Database is bought by RIETI from the JMDC Cooperation for the project. The author would like to thank the project leader, Yoichi Sekizawa, for his sincere cooperation. This study was approved by the Institutional Review Boards of the University of Tokyo (21-8). We would also like to thank an anonymous reviewer for his/her helpful comments and suggestions.

\section{Conflicts of Interest}

The author declares no conflicts of interest regarding the publication of this paper.

\section{References}

[1] World Health Organization (2020) World Health Statistics 2020: Monitoring Health for the SDGs, Sustainable Development Goals. World Health Organization, Geneva.

[2] World Health Organization (2019) Hypertension. 
https://www.who.int/news-room/fact-sheets/detail/hypertension\#: :text=Hypertens ion $\% 20 \% 2 \mathrm{D} \% 20$ or $\% 20$ elevated $\% 20$ blood $\% 20$ pressure, $\% 2 \mathrm{D} \% 20$ and $\% 20$ middle $\% 2 \mathrm{D}$ income $\% 20$ countries

[3] World Health Organization (2021) Raised Blood Pressure (SBP $\geq 140$ OR DBP $\geq 90$; Crude Estimate: Last Updated 2017-11-17).

https://www.who.int/data/gho/data/indicators/indicator-details/GHO/raised-bloodpressure-(sbp- $=140$-or- $d b p-=90)$-(crude-estimate)

[4] Benjamin, E.J., Virani, S.S., Callaway, C.W., Chamberlain, A.M., Chang, A.R., Cheng, S., et al. (2018) Heart Disease and Stroke Statistics-2018 Update: A Report from the American Heart Association. Circulation, 137, e67-e492.

https://doi.org/10.1161/CIR.0000000000000558

[5] Blood Pressure UK (2020) The Blood Pressure Chart.

http://www.bloodpressureuk.org/your-blood-pressure/understanding-your-blood-p ressure/what-do-the-numbers-mean/

[6] Whelton, P.K., Carey, R.M., Arrow, W.S. Casey, D.E., Collins, K.J., Himmelfarb, C.D., et al. (Writing Committee Members) (2018) 2017 ACC/AHA/AAPA/ $\mathrm{ABC} / \mathrm{ACPM} / \mathrm{AGS} / \mathrm{APhA} / \mathrm{ASH} / \mathrm{ASPC} / \mathrm{NMA} / \mathrm{PCNA}$ Guideline for the Prevention, Detection, Evaluation, and Management of High Blood Pressure in Adults: A Report of the American College of Cardiology/American Heart Association Task Force on Clinical Practice Guidelines. Hypertension, 71, e13-e115.

https://doi.org/10.1161/HYP.0000000000000065

[7] Whelton, P.K., Carey, R.M., Arrow, W.S., et al. (2018) 2017 Guideline for Blood Pressure in Adults. American College of Cardiology, Washington DC.

http://www.acc.org/latest-in-cardiology/ten-points-to-remember/2017/11/09/11/41/ 2017-guideline-for-high-blood-pressure-in-adults

[8] Carey, R.M. and Whelton P.K. for the 2017 ACC/AHA Hypertension GuidelineWriting Committee (2018) Prevention, Detection, Evaluation, and Management of High Blood Pressure in Adults: Synopsis of the 2017 American College of Cardiology/American Heart Association Hypertension Guideline. Annals of Internal Medicine, 168, 351-335. https://doi.org/10.7326/M17-3203

[9] Center for Disease Control and Prevention (2020) Facts about Hypertension. https://www.cdc.gov/bloodpressure/facts.htm

[10] Ostchega, Y., Fryar, C.D., Nwankwo, T. and Nguyen, D.T. (2020) Hypertension Prevalence among Adults Aged 18 and Over: United States, 2017-2018. NCHS Data Brief, No. 364, 1-8.

[11] American Diabetes Association (2018) Cardiovascular Disease and Risk Management: Standards of Medical Care in Diabetes-2018. Diabetes Care, 41, S86-S104. https://doi.org/10.2337/dc18-S009

[12] LeFevre, M. (2018) ACC/AHA Hypertension Guideline: What is New? What Do We Do? American Family of Physician, 97, 372-373.

[13] Williams, B., Mancia, G., Spiering, W., Agabiti Rosei, E., Azizi, M., Burnier, M., et al. (2018) 2018 ESC/ESH Guidelines for the Management of Arterial Hypertension. European Heart Journal, 39, 3021-3104. https://doi.org/10.1093/eurheartj/ehy339

[14] Nerenberg, K.A., Zarnke, K.B., Leung, A.A., Dasgupta, K., Butalia, S., McBrien, K., et al. (2018) Hypertension Canada's 2018 Guidelines for Diagnosis, Risk Assessment, Prevention, and Treatment of Hypertension in Adults and Children. Canadian Journal of Cardiology, 34, 506-525. https://doi.org/10.1016/j.cjca.2018.02.022

[15] Goupil, R., Lamarre-Cliché, M. and Vallee, M. (2018) The 2017 American College of Cardiology/American Heart Association vs Hypertension Canada High Blood 
Pressure Guidelines and Potential Implications. Canadian Journal of Cardiology, 34, 665-669. https://doi.org/10.1016/j.cjca.2018.01.011

[16] Hirawa, N., Umemura, S. and Ito, S. (2019) Viewpoint on Guidelines for Treatment of Hypertension in Japan. Circulation Research, 124, 981-983. https://doi.org/10.1161/CIRCRESAHA.119.314991

[17] Ministry of Health, Labour and Welfare (2019) Heisei 29 nenkanjashosa no gayou (Summary of the Patient Survey in 2017). Ministry of Health, Labour and Welfare, Tokyo. (In Japanese)

[18] Ministry of Health, Labour and Welfare (2020) Heisei 30 nendokokuminiryouhi no gayou (Summary of National Medical Expenditures in Fiscal Year 2018). Ministry of Health, Labour and Welfare, Tokyo. (In Japanese)

[19] Boston University and National Heart, Lung, \& Blood Institute (2021) Framingham Heart Study. https://www.framinghamheartstudy.org

[20] Joffres, M.R., Mamet, P., MacLean, D.R., L'italien, G.J. and Fodor, G. (2001) Distribution of Blood Pressure and Hypertension in Canada and the United States. American. Journal of Hypertension, 14, 1099-1105.

https://doi.org/10.1016/S0895-7061(01)02211-7

[21] Prospective Studies Collaboration (2002) Age-Specific Relevance of Usual Blood Pressure to Vascular Mortality: A Meta-Analysis of Individual Data for One Million Adults in 61 Prospective Studies. Lancet, 360, 1903-1913.

https://doi.org/10.1016/S0140-6736(02)11911-8

[22] Rapsomaniki, E., Timmis, A., George, J., Pujades-Rodriguez, M., Shah, A.D., Denaxas, S., et al. (2014) Blood Pressure and Incidence of Twelve Cardiovas-cular Diseases: Lifetime Risks, Healthy Life-Years Lost, and Age-Specific Associations in 1.25 Million People. Lancet, 383, 1899-1911. https://doi.org/10.1016/S0140-6736(14)60685-1

[23] The SPRINT Research Group (2015) A Randomized Trial of Intensive versus Standard Blood-Pressure Control. New England Journal of Medicine, 373, 2103-2116. https://doi.org/10.1056/NEJMoa1511939

[24] The ACCORD Study Group (2010) Effect of Intensive Blood-Pressure Control in Type 2 Diabetes Mellitus. New England Journal of Medicine, 362, 1575-1585. https://doi.org/10.1056/NEJMoa1001286

[25] Ettehad, D., Emdin, C.A., Kiran, A., Anderson, S.G., Callender, T., Emberson, J., et al. (2016) Blood Pressure Lowering for Prevention of Cardiovascular Disease and Death: A Systematic Review and Meta-analysis. Lancet, 387, 957-967. https://doi.org/10.1016/S0140-6736(15)01225-8

[26] Muntner, P., Carey, R.M., Gidding, S., Jones, D.W., Taler, S.J., Wright Jr., J.T., et al. (2018) Potential U.S. Population Impact of the 2017 ACC/AHA High Blood Pressure Guideline. Journal of the American College of Cardiology, 71, 109-118. https://doi.org/10.1016/j.jacc.2017.10.073

[27] Ministry of Health, Labour and Welfare (2020) National Health and Nutrition Survey in Japan, 2019. Ministry of Health, Labour and Welfare, Tokyo. (In Japanese)

[28] Department of Epidemiology and Public Health, Graduate School of Medical Sciences, Kyushu University (2021) Higayama Study. http://www.hisayama.med.kyushu-u.ac.jp/en/

[29] Honda, T., Yoshida, D., Hata, J., Hirakawa, Y., Ishida, Y., Shibata, M., et al. (2018) Development and Validation of Modified Risk Prediction Models for Cardiovascular Disease and its Subtypes: The Hisayama Study. Atherosclerosis, 279, 38-44. https://doi.org/10.1016/j.atherosclerosis.2018.10.014 
[30] Fujiyoshi, A., Ohkubo, T., Miura, K., Murakami, Y., Nagasawa, S., Okamura, T., et al. (2012) Blood Pressure Categories and Log-term Risk of Cardio-vascular Disease According to Age Group in Japanese Men and Women. Hypertension Research, 35, 947-953. https://doi.org/10.1038/hr.2012.87

[31] Asayama, K., Satoh, M., Murakami, Y., Ohkubo, T., Nagasawa, S., Tsuji, I., et al. (2014) Cardiovascular Risk with and without Antihypertensive Drug Treatment in the Japanese General Population Participant-Level Meta-Analysis. Hypertension, 63, 1189-1197. https://doi.org/10.1161/HYPERTENSIONAHA.113.03206

[32] Nawata, K., Matsumoto, A., Kajihara, R. and Kimura, M. (2017) Evaluation of the Distribution and Factors Affecting Blood Pressure Using Medical Checkup Data in Japan. Health, 9, 124-137. https://doi.org/10.4236/health.2017.91009

[33] Nawata, K. and Kimura, M. (2017). Reliability of Blood Pressure Measurements: An Analysis of the White Coat Effect and its Fluctuations. Health, 9, 506-519. https://doi.org/10.4236/health.2017.93036

[34] Nawata, K., Sekizawa, Y. and Kimura, M. (2018) Evaluation of Blood Pressure Control Medicines using Health and Medical Checkup Data in Japan: Alternative Methods for Randomized Controlled Trials. Health, 10, 587-603.

https://doi.org/10.4236/health.2018.105047

[35] Yu, J., Wei, Y., Jing, Y. and Gao, Y. (2021) Effect of Acupuncture on Essential Hypertension: A Protocol for Systematic Review and Meta-Analysis. Medicine, 100, e25572. https://doi.org/10.1097/MD.0000000000025572

[36] Nawata, K. and Kimura, M. (2018) Does High Systolic Blood Pressure Truly Increase Medical Expenditure? An Empirical Analysis of the New 2017 ACC/AHA Hypertension Guideline. Health, 10, 1044-1065.

https://doi.org/10.4236/health.2018.108079

[37] Nawata, K. and Kimura, M. (2018) Empirical Studies of Effects of High Blood Pressure on Medical Costs and Heart Disease: Is the 2017 ACC/AHA Guideline Supported by Enough Evidence? Health, 10, 1498-1519. https://doi.org/10.4236/health.2018.1011115

[38] Nawata, K., Sugano, H. and Kimura, M. (2019) An Analysis of the Effects of Blood Pressure and Antihypertensive Drugs on Heart Disease. Health, 11, 792-816. https://doi.org/10.4236/health.2019.116064

[39] Nawata, K. (2020) Risk Factors Affecting Ischemic Stroke: Potential Side Effect of Antihypertensive Drugs. Health, 12, 437-455. https://doi.org/10.4236/health.2020.125035

[40] Kaneko, H., Yano, Y., Ito, H., Morita, K., Kiriyama, H., Kamon, T., et al. (2021) Association of Blood Pressure Classification Using the 2017 American College of Cardiology/American Heart Association Blood Pressure Guideline with Risk of Heart Failure and Atrial Fibrillation. Circulation, 143, 2244-2253. https://doi.org/10.1161/CIRCULATIONAHA.120.052624

[41] Akbay, E., Çoner, A., Akıncı, S., Rıza Demir, A. and Toktamiş, A. (2021) Which Is Responsible for Target Organ Damage in Masked Hypertension? Is It an Increase in Blood Pressure or a Disruption of the Circadian Rhythm? Clinical and Experimental Hypertension, 18, 1-7. https://doi.org/10.1080/10641963.2021.1916946

[42] U.S. National Library of Medicine (2021) High Blood Pressure Medicines. https://medlineplus.gov/ency/article/007484.htm

[43] Li, W., Moore, M.J., Vasilieva, N., Sui, J., Wong, S.K., Berne, M.A., et al. (2003) Angiotensin-Converting Enzyme 2 Is a Functional Receptor for the SARS Coronavirus. Nature, 426, 450-454. https://doi.org/10.1038/nature02145 
[44] Kuba, K., Imai, Y., Rao, S., Gao, H., Guo, F., Guan, B., et al. (2005) A Crucial Role of Angiotensin Converting Enzyme 2 (ACE2) in SARS Coronavirus-Induced Lung Injury. Nature Medicine, 11, 875-879. https://doi.org/10.1038/nm1267

[45] Hoffmann, M., Kleine-Weber, H., Schroeder, S., Krüger, N., Herrler, T., Erichsen, S., et al. (2020) SARS-CoV-2 Cell Entry Depends on ACE2 and TMPRSS2 and Is Blocked by a Clinically Proven Protease Inhibitor. Cell, 181, 271-280.E8. https://doi.org/10.1016/j.cell.2020.02.052

[46] Bourgonje, A.R., Abdulle, A.E., Timens, W., Hillebrands, J.-L., Navis, G.J., Gordijn, S.J., et al. (2020) Angiotensin-Converting Enzyme 2 (ACE2), SARS-CoV-2 and the Pathophysiology of Coronavirus Disease 2019 (COVID-19). Journal of Pathology, 251, 228-248. https://doi.org/10.1002/path.5471

[47] European Medicines Agency (EMA) (2020) Latest Data Support Continued Use of ACE Inhibitors and ARB Medicines during COVID-19 Pandemic.

https://www.ema.europa.eu/en/news/latest-data-support-continued-use-ace-inhibit ors-arb-medicines-during-covid-19-pandemic

[48] World Health Organization (2020) COVID-19 and the Use of Angiotensin-Converting Enzyme Inhibitors and Receptor Blockers.

https://www.who.int/news-room/commentaries/detail/covid-19-and-the-use-of-ang iotensin-converting-enzyme-inhibitors-and-receptor-blockers

[49] Bozkurt, B., Kovacs, R. and Harrington, B. (2020) HFSA/ACC/AHA Statement Addresses Concerns Re: Using RAAS Antagonists in COVID-19. American College of Cardiology, Washington DC.

https://www.acc.org/latest-in-cardiology/articles/2020/03/17/08/59/hfsa-acc-aha-sta tement-addresses-concerns-re-using-raas-antagonists-in-covid-19

[50] Emilsson, V., Gudmundsson, F.E., Aspelund, T., Jonsson, B.G., Gudjonsson, A., Launer, L.J., et al. (2020) Antihypertensive Medication Uses and Serum ACE2 Levels ACEIs/ARBs Treatment Does Not Raise Serum Levels of ACE2. medRxiv. (Preprint) https://doi.org/10.1101/2020.05.21.20108738

[51] Fang, L., Karakiulakis, G. and Roth, M. (2020) Are Patients with Hypertension and Diabetes Mellitus at Increased Risk for COVID-19 Infection? Lancet Respiratory Medicine, 8, e21. https://doi.org/10.1016/S2213-2600(20)30116-8

[52] Zhang, H., Penninger, J.M., Li, Y., Zhong, N. and Slutsky, A.S. (2020) Angiotensin-Converting Enzyme 2 (ACE2) as a SARS-CoV-2 Receptor: Molecular Mechanisms and Potential Therapeutic Target. Intensive Care Medicine, 46, 586-590. https://doi.org/10.1007/s00134-020-05985-9

[53] Gao, C., Cai, Y., Zhang, K., Zhou, L., Zhang, Y., Zhang, X., et al. (2020) Association of Hypertension and Antihypertensive Treatment with COVID-19 Mortality: A Retrospective Observational Study. European Heart Journal, 41, 2058-2066. https://doi.org/10.1093/eurheartj/ehaa433

[54] Gracia-Ramos, A.E. (2020) Is the ACE2 Overexpression a Risk Factor for COVID-19 Infection? Archives of Medical Research, 51, 345-346.

https://doi.org/10.1016/j.arcmed.2020.03.011

[55] Gurwitz. D. (2020) Angiotensin Receptor Blockers as Tentative SARS-CoV-2 Therapeutics. Drug Development Search, 81, 537-540.

https://doi.org/10.1002/ddr.21656

[56] Kreutz, R., Algharably, E.A.E., Azizi, M., Dobrowolski, P., Guzik, T., Januszewicz, A., et al. (2020) Hypertension, the Renin-Angiotensin System, and the Risk of Lower Respiratory Tract Infections and Lung Injury: Implications for COVID-19. Cardiovascular Research, 116, 1688-1699. https://doi.org/10.1093/cvr/cvaa097 
[57] Lee, I.T., Nakayama, T., Wu, C., Goltsev, Y., Jiang, S., Gall, P.A., et al. (2020) ACE2 Localizes to the Respiratory Cilia and is not Increased by ACE Inhibitors or ARBs. Nature Communications, 11, Article No. 5453. https://doi.org/10.1038/s41467-020-19145-6

[58] Liu, M., Wang, T., Zhou, Y., Zhao, Y., Zhang, Y. and Li, J. (2020) Potential Role of ACE2 in Coronavirus Disease 2019 (COVID-19) Prevention and Management. Journal of Internal Medicine, 8, 9-19. https://doi.org/10.2478/jtim-2020-0003

[59] Mourad, J. and Levy, B.I. (2020) Interaction between RAAS Inhibitors and ACE2 in the Context of COVID-19. Nature Reviews of Cardiology, 17, 313. https://doi.org/10.1038/s41569-020-0368-x

[60] Ryan, J.J., Melendres-Groves, L., Zamanian, R.T., Oudiz, R.J., Chakinala, M., Rosenzweig, E.B., et al. (2020) Patients with Pulmonary Arterial Hypertension during the Coronavirus (COVID-19) Pandemic. Pulmonary Circulation, 10, 1-7. https://doi.org/10.1177\%2F2045894020920153

[61] Schiffrin, E.L., Flack, J.M., Ito, S., Muntner, P. and Clinton Webb, R. (2020) Hypertension and COVID-19. American Journal of Hypertension, 33, 373-374. https://doi.org/10.1093/ajh/hpaa057

[62] Sriram, K. and Insel, P.A. (2020) Risks of ACE Inhibitor and ARB Usage in COVID-19: Evaluating the Evidence. Clinical Pharmacology \& Therapeutics, 108, 236-241. https://doi.org/10.1002/cpt.1863

[63] Tignanelli, C.J., Ingraham, N.E., Sparks, M.A., Reilkoff, R., Bezdicek, T., Benson, B., et al. (2020) Antihypertensive Drugs and Risk of COVID-19? Lancet Respiratory Medicine, 8, e30-e31. https://doi.org/10.1016/S2213-2600(20)30153-3

[64] Wysocki, J., Lores. E., Ye, M., Soler, M.J. and Batlle, D. (2020) Kidney and Lung ACE2 Expression after an ACE Inhibitor or an Ang II Receptor Blocker: Implications for COVID-19. Journal of American Society of Nephrology, 31, 1941-1943. https://doi.org/10.1681/ASN.2020050667

[65] Zheng, Y., Ma, Y., Zhang, J. and Xie, X. (2020) COVID-19 and the Cardiovascular System. Nature Reviews Cardiology, 17, 259-260.

https://doi.org/10.1038/s41569-020-0360-5

[66] Bonner, C., Cvejic, E., Ayre, J., Isautier, J., Semsarian, C., Nickel, B., et al. (2021) The Psychological Impact of Hypertension During COVID-19 Restrictions: Retrospective Case-Control Study. JMIRx Med, 2, e25610. https://doi.org/10.2196/25610

[67] Bottinoa, L.G. and Fuchsa, F.D. (2021) Response to the letter to the editor entitled "Angiotensin-II receptor blockers or angiotensin converting enzyme inhibitors for the treatment of hypertension amid COVID-19 pandemic." Expert Review of Cardiovascular Therapy, 19, 189-190. https://doi.org/10.1080/14779072.2021.1862548

[68] Hosseinzadeh, R., Goharrizi, M.A.S., Bahardoust, M., Ghorbani Alvanegh, A., Reza Ataee, M., Bagheri, M., et al. (2021) Should All Patients with Hypertension Be Worried about Developing Severe Coronavirus Disease 2019 (COVID-19)? Clinical Hypertension, 27, Article No. 3. https://doi.org/10.1186/s40885-021-00161-7

[69] Miyazawa, D. (2021) Why Obesity, Hypertension, Diabetes, and Ethnicities Are Common Risk Factors for COVID-19 and H1N1 Influenza Infections. Journal of Medical Virology, 93, 127-128. https://doi.org/10.1002/jmv.26220

[70] White, H. (1980). A Heteroskedasticity-Consistent Covariance Matrix Estimator and a Direct Test for Heteroskedasticity. Econometrica, 48, 817-838. https://doi.org/10.2307/1912934

[71] Miura, K., Nagai, M. and Ohkubo, T. (2013) Epidemiology of Hypertension in Japan: Where are We Now? Circulation Journal, 77, 2226-2231. 
[72] Chobanian, A.V., Bakris, G.L., Black, H.B., Cushman, W.C., Green, L.A., Izzo Jr., J.L., et al. (2003) Seventh Report of the Joint National Committee on Prevention, Detection, Evaluation, and Treatment of High Blood Pressure. Hypertension, 42, 1206-1252. https://doi.org/10.1161/01.HYP.0000107251.49515.c2 